\title{
Analisis Penilaian Sikap Siswa Biologi Selama Pembelajaran Daring Pada Era Tatanan Baru
}

\author{
Eryuni Ramdhayani $^{1)}$, Wiwi Noviati ${ }^{1)^{*}}$, Syafruddin $^{1)}$, Linda Deniati $^{1)}$, Erna Kurniati ${ }^{1)}$ \\ ${ }^{1)}$ Universitas Samawa, Sumbawa Besar \\ *wiwinoviati15@gmail.com
}

Abstrak: Penerapan pembelajaran daring tentunya diiringi oleh permasalahan baru dalam proses pembelajaran maupun dalam mengevaluasi siswa. Permasalahan pembelajaran daring yang diterapkan dalam era tatanan baru tentunya muncul terkait kesulitan guru dalam mengevaluasi siswa terutama dalam menilai sikap siswa selama pembelajaran daring. Penelitian ini bertujuan untuk mengetahui bagaimana cara guru dalam mengakses penilaian sikap siswa selama proses pembelajaran agar dapat menjadi refrensi terhadap guru yang kesulitan dalam memberikan penilaian sikap terhadap siswa. Penelitian ini menggunakan metode kualitatif melalui pendekatan deskritif. Teknik pengambilan sampel menggunakan Teknik purposive sampling. Teknik pengumpulan data menggunakan kuisioner terkait mengenai analisis teknik penilaian sikap siswa selama pembelajaran daring pada era tatanan baru yang diisi oleh responden. Keabsahan data dalam penelitian ini menggunakan triangulasi data. Berdasarkan hasil penelitian yang telah dilakukan diperoleh bahwa penilaian sikap dalam pembelajaran daring sulit dilakukan dan hasilnya kurang akurat, Penilaian sikap selama pembelajaran daring masih sebatas guru melihat respon siswa dalam hal mengerjakan tugas yang diberikan., dan penilaian sikap menjadi hal yang perlu untuk dibenahi selama pembelajaran daring di era new normal dari segi kesiapan guru menyiapkan instrument dan mengkondisikan siswa agar mengembangkan karakter selama pembelajaran daring.

Kata Kunci: Penilaian Sikap, Pembelajaran Daring

\section{Pendahuluan}

Permasalahan dunia sekarang yang sedang dilanda pandemi Covid-19, sehingga tentunya berdampak bagi segala bidang tidak terkecuali dalam bidang Pendidikan. Dunia pendidikan pun tidak lepas dari tatanan kenormalan baru. Sejak awal pandemi ini muncul dan menghambat pembelajaran tatap muka di ruang-ruang kelas, model belajar dari rumah (BDR) menjadi kenormalan baru dalam dunia pendidikan sehingga mengharuskan penggunaan teknologi informasi khususnya internet. Menurut (Noviati 2020) Teknologi informasi sangatlah berdampak pada Pendidikan di Indonesia khususnya, misalnya dalam hal mendapat referensi terbaru dan ter $u p$ to date bagi guru dalam hal materi maupun media pembelajaran.

Penerapan pembelajaran daring tentunya diiringi oleh permasalahan baru dalam proses pembelajaran maupun dalam mengevaluasi siswa. Permasalahan pembelajaran daring yang diterapkan dalam era tatanan baru tentunya muncul terkait kesulitan guru dalam mengevaluasi siswa terutama dalam menilai sikap siswa selama pembelajaran daring. Karena pendidikan tidak hanya mengajarkan pengetahuan saja tetapi juga pada penilaian sikap siswa sesuai dengan tujuan pendidikan nasional yang diharapkan. Hal ini didukung oleh (Ramdhayani, Ibrahim, and Madlazim 2017) bahwa pendidikan tidak hanya membelajarkan pengetahuan kognitif dan keterampilan saja melainkan yang paling penting adalah cara menanamkan nilai-nilai untuk membentuk sikap positif siswa dan mampu mengimplementasikannya dalam kehidupan sehari-hari.

Tujuan pembelajaran ranah afektif adanya stimulus-respon yang dapat membentuk sikap baru yang berorientasi pada nilai-nilai karakter setiap individu. Penilaian ranah afektif merupakan sisi kejiwaan siswa yang relative sulit untuk diukur (Alifah 2019). Upaya penilaiaan sikap merupakan kegiatan yang dilakukan oleh guru untuk memperoleh informasi deskriptif mengenai perilaku siswa yang meliputi penilaian sikap spiritual dan penilaian sikap sosial. Menurut hasil penelitian (Zuhera, Habibah, and Mislinawati 2017) faktor kesulitan yang 
dialami guru dalam penilaian sikap yaitu keterbatasan waktu yang dimiliki oleh guru. Didukung juga oleh (Retnawati 2016) bahwa mayoritas yang dikeluhkan oleh guru adalah penilaian sikap Pada saat mengajar, guru harus membagi waktu antara penyampaian materi, pemberian tugas dan proses evaluasi. Hal inilah yang menyulitkan guru dalam melakukan penilaian sikap siswa. Penilaian sikap siswa harus dilakukan secara individu dan langsung bertatap muka. Sehingga, keterbatasan waktu yang dimiliki menjadi penghambat bagi guru. Apalagi penilaian sikap dengan adanya tatanan baru ini mengharuskan guru melakukan pembelajaran daring, hal ini tentunya menjadi kendala baru yang dialami guru dalam hal menilai sikap.

Bertolak dari permasalahan tersebut maka penulis tertarik untuk melakukan penelitian yaitu menganalisis penilaian sikap siswa selama pembelajaran daring pada era tatanan baru. Hal ini bertujuan untuk mengetahui bagaimana cara guru dalam mengakses penilaian sikap siswa selama proses pembelajaran agar dapat menjadi refrensi terhadap guru yang kesulitan dalam memberikan penilaian sikap terhadap siswa.

\section{Metode Penelitian}

Penelitian ini menggunakan metode kualitatif melalui pendekatan deskritif. Teknik pengambilan sampel menggunakan Teknik purposive sampling yaitu teknik sampling nonrandom sampling dimana peneliti menentukan pengambilan sampel dengan cara menetapkan ciri-ciri khusus yang sesuai dengan tujuan penelitian sehingga diharapkan dapat menjawab permasalahan penelitian. Sampel penelitian yaitu 5 Guru Biologi SMA/MA di Sumbawa. Teknik pengumpulan data menggunakan kuisioner terkait mengenai analisis penilaian sikap siswa selama pembelajaran daring pada era tatanan baru yang diisi oleh responden. Keabsahan data dalam penelitian ini menggunakan triangulasi. Triangulasi adalah Teknik pemeriksaan keabsahan data yang memanfaatkan sesuatu yang lain di luar data sebagai pembanding. Pada penelitian ini penulis menggunakan triangulasi sumber yaitu dengan mengecek data dari beberapa sumber. Sedangkan untuk analisis data dalam penelitian ini menggunakan analisis data menggunakan model analisis data interaktif yaitu berdasarkan data yang diperoleh menurut Milles dan Huberman sebagai berikut: 1) Reduksi data, yang diartikan sebagai pemilihan, pemusatan perhatian pada penyederhanaan dan transformasi data kasar yang muncil dari catatan tetulis di lapangan; 2) Penyajian data, sekumpulan informasi informasi tersusun yang memberi adanya kemungkinan penarikan kesimpulandean pengambilan Tindakan; 3) Menarik kesimpulan, sebagaian dari satu kegiatan konfigurasi yang utuh. Kesimpulan juga diverifikasi selama penelitian berlangsung. Verifikasi yaitu pemikiran kembali atau tinjauan ulang dari catatan di lapangan.

\section{Hasil dan Pembahasan}

Hasil penelitian ini diperoleh melalui kuisioner yang telah disi oleh guru biologi di SMA/MA, kemudian data tersebut di analisis secara deskriptif mengenai bagaimana penilain sikap siswa selama pembelajaran daring pada era tatanan baru. Kriteria responden dalam penelitian ini adalah guru yang melakukan proses pembelajaran secara daring pada era tatanan baru. Dalam menganalisis data peneliti membuat daftar pernyataan dalam bentuk kuisioner terkait bagaimana penilaian sikap siswa selama pembelajaran daring. Hal ini untuk dapat merangkum bagaimana guru dalam menilai sikap siswa.

Menurut (Setiawan and Suardiman 2018) penilaian sikap di dunia pendidik kurang diperhatikan, padahal sikap sosial yang muncul dianggap tidak biasa. Dalam proses pembelajaran daring yang dirasa sulit oleh guru adalah tahap penilaian terutama penilaian sikap. Hal ini disebabkan karena proses penilaian sikap seyongyanya dilakukan dengan observasi secara langsung oleh guru selama proses pembelajaraan. Berdasarkan hasil penelitian dari semua responden menyatakan bahwa "Penilaian sikap yang dilakukan secara daring merupakan suatu hal yang sangat sulit dilakukan oleh seorang guru”. Dengan adanya kesulitan ini tentu penilaian yang telah dilakukan secara daring kurang akurat. Dari pernyataan semua reponden juga menyatakan bahwa proses penilaian sikap yang dilakukan secara daring tidak akurat karena guru tidak bisa melihat secara langsung sikap yang muncul selama proses pembelajaran. Hal ini sesuai dengan pendapat (Audina, Susetyo, and Arifin 2019) bahwa penilaian sikap dengan Teknik observasi dilakukan oleh guru saat proses kegiatan belajar mengajar, jika muncul sikap negarif guru akan lansung mencatat.

Selama proses pembelajaran daring penilaian sikap dilakukan guru melalui beberapa strategi. Berdasarkan hasil penelitian terhadap beberapa responden menunjukkan sikap setuju dengan melihat cara siswa merespon tugas yang telah diberikan oleh guru melalui media online, sikap jujur serta motivasi siswa dalam belajar. 
Menurut (Arif Rahman 2018) bahwa motivasi berfungsi sebagai pendorong, penggerak dan pengarah kegiatan siswa dalam dalam belajar. Motivasi adalah dorongan dasar yang menggerakkan seseorang bertingkah laku (Mariamah and Susantri 2018). Motivasi sangat berperan dalam menunjukkan sikap yang dimunculkan siswa dalam proses pembelajaran. Selain motivasi cara siswa merespon tugas yang diberikan guru dapat menjadipatokan guru dalam menilai sikap siswa. Hal ini sesuai dengan pendapat (Prawati 2016) bahwa dengan memberikan tugas pada siswa daapat meningkatkan sikap positif terhadap belajar dan pengalaman belajarnya. Misalnya sikap jujur, bertanggungjawab, disiplin, gigih, dan kepercayaan diri. Selain itu responden berinisial "S" dan " $T$ " setuju dengan pernyataan bahwa penilaian sikap dapat dilakukan melalui teman sejawat. Hai ini sesuai dengan pendapat (Tiara and Sari 2019) bahwa guru melakukan penilaian sikap melalui observasi, penilaian diri, penilaian teman sejawat siswa dan jurnal. Penilaian antar teman atau teman sejawat dilakukan untuk mengetahui objektivitas siswa. Penilaian antar teman atau teman sejawat dan penilaian diri dilakukan sekurang-kurangnya satu kali dalam satu semester (Puspita Sari and Sudiana 2019).

Guru dalam menilai sikap siswa tentunya dilihat dari adanya sikap yang ditunjukkan oleh siswa selama kegiatan pembelajaran hal ini dilihat dari hasil responden dimana ada 2 responden menjawab sangat setuju dan 3 responden menjawab setuju bahwa sikap yang muncul dari seorang siswa merupakan salah satu cara untuk membantu para guru dalam proses penilaian sikap dalam pembelajaran daring. Hasil ini juga diperkuat dengan pernnyataan bahwa siswa yang mengerjakan tugas dengan jujur dan mengumpulkan tugasnya dengan tepat waktu dapat membantu guru dalam proses penilaian sikap selama pembelajaran daring dimana 2 responden menjawab setuju dan 3 responden yang menjawab sangat setuju. Namun dalam hal ini guru menemukan masalah dalam hal membenetuk sikap siswa dalam pembelajaran daring karena sulitnya mengkondisikan siswa dalam memunculkan sikap yang ingin dinilai oleh guru. Hal ini didukung oleh penelitian (Kusaeri 2019) bahwa untuk memunculkan sikap perlu dilakukan setting wahana situasi yang dapat dibagi pelaksanaannya dalam proses pembelajaran dan di luar pembelajaran maka diperlukan sekolah/madrasah yang menjadi tempat menyenangkan dan kondusif bagi siswa belajar.

Penilaian sikap menjadi hal yang perlu untuk dibenahi selama pembelajaran daring di era new normal ini. Baik dari segi kesiapan guru dalam hal menyiapkan instrument yang cocok dalam pembelajaran daring. Kemampuan dan keterampilan serta keahlian guru untuk mengotomatiskan pengajaran, seperti penilaian digital dapat memantau kemajuan siswa dengan platform yang ada di sekolah (Mardiana 2020). Guru harus mampu mengkondisikan siswa agar dapat belajar menyenangkan dan mengembangkan karakter mereka meskipun dilakukan melalui pembelajaran daring sehingga munculnya karakter kepercayaan diri dan tentunya berdampak pada munculnya karakter yang lainnya. Karakter kepercayaan diri siswa ditentukan oleh kemampuan guru menggunakan pendekatan yang menstimulus siswa aktif (Ade Mutiarawati 2020).

\section{Simpulan}

Berdasarklan hasil penelitian ada beberapa kesimpulan yang dapat diperoleh yaitu: Proses penilaian sikap yang dilakukan secara daring tidak akurat karena guru tidak bisa melihat secara langsung sikap yang muncul selama proses pembelajaran. Selain itu, penilaian sikap menjadi hal yang perlu untuk dibenahi selama pembelajaran daring di era new normal. Baik dari segi kesiapan guru dalam hal menyiapkan instrument yang cocok dalam pembelajaran daring dan mengkondisikan siswa agar dapat belajar menyenangkan sehingga dapat mengembangkan karakter.

\section{Daftar Pustaka}

Ade Mutiarawati. 2020. "Pengaruh Pendekatan Konstruktivisme Terhadap Karakter Kepercayaan Diri Siswa Dalam Pembelajaran Matematika Di SMPN 15 Kota Bekasi.” JURNAL PENDIDIKAN MIPA. doi: 10.37630/jpm.v9i2.228.

Alifah, Fitriani Nur. 2019. "PENGEMBANGAN STRATEGI PEMBELAJARAN AFEKTIF.” Tadrib: Jurnal Pendidikan Agama Islam. doi: 10.19109/tadrib.v5i1.2587.

Arif Rahman. 2018. "Hubungan Motivasi Dan Sikap Siswa Terhadap Prestasi Belajar Matematika Kelas VIII SMP Negeri 1 Wera.” JURNAL PENDIDIKAN MIPA. doi: 10.37630/jpm.v8i1.60.

Audina, Ise, Susetyo Susetyo, and M. Arifin. 2019. "PENILAIAN SIKAP SISWA DALAM PEMBELAJARAN 
BAHASA INDONESIA OLEH GURU KELAS VII DI SMP NEGERI 1 KOTA BENGKULU.” Jurnal Ilmiah KORPUS. doi: 10.33369/jik.v2i2.6520.

Kusaeri, Kusaeri. 2019. "PENILAIAN SIKAP DALAM PEMBELAJARAN MATEMATIKA.” JPM : Jurnal Pendidikan Matematika. doi: 10.33474/jpm.v5i2.1588.

Mardiana, Harisa. 2020. "Lecturers' Attitudes towards Online Teaching in the Learning Process." Register Journal. doi: 10.18326/rgt.v13i1.77-98.

Mariamah, and Susantri. 2018. "Penerapan Model Accelerated Learning Untuk Meningkatkan Motivasi Belajar Siswa Kelas X4 SMAN 3 Kota Bima.” JURNAL PENDIDIKAN MIPA. doi: 10.37630/jpm.v8i1.44.

Noviati, Wiwi. 2020. "Kesulitan Pembelajaran Online Mahasiswa Pendidikan Biologi Di Tengah Pandemi Covid19.” Jurnal Pendidikan MIPA.

Prawati, Siska. 2016. "Penerapan Metode Pemberian Tugas Untuk Meningkatkan Hasil Belajar Siswa Dalam Pembelajaran IPS Pada Siswa Kelas V SDN No 1 Pangalasiang.” Jurnal Kreatif Tadulako Online.

Puspita Sari, Ni Putu Nanik, and I. Ketut Sudiana. 2019. "PENILAIAN SIKAP SEBAGAI DAMPAK PENGIRING PEMBELAJARAN PRAKTIKUM KIMIA.” Jurnal Pendidikan Kimia Undiksha. doi: 10.23887/jjpk.v3i2.21143.

Ramdhayani, Eryuni, Muslimin Ibrahim, and Madlazim Madlazim. 2017. "PEMBELAJARAN SIKAP MELALU ANALOGI DALAM MENGAJARKAN BIOLOGI.” JPPS (Jurnal Penelitian Pendidikan Sains). doi: 10.26740/jpps.v5n1.p874-884.

Retnawati, Heri. 2016. "HAMBATAN GURU MATEMATIKA SEKOLAH MENENGAH PERTAMA DALAM MENERAPKAN KURIKULUM BARU.” Jurnal Cakrawala Pendidikan. doi: 10.21831/cp.v3i3.7694.

Setiawan, Ari, and Siti Partini Suardiman. 2018. "Assessment of the Social Attitude of Primary School Students.” Research and Evaluation in Education. doi: 10.21831/reid.v4i1.19284.

Tiara, Shintia Kandita, and Eka Yuliana Sari. 2019. "ANALISIS TEKNIK PENILAIAN SIKAP SOSIAL SISWA DALAM PENERAPAN KURIKULUM 2013 DI SDN 1 WATULIMO.” EduHumaniora | Jurnal Pendidikan Dasar Kampus Cibiru. doi: 10.17509/eh.v11i1.11905.

Zuhera, Yuni, Sy Habibah, and Mislinawati. 2017. "Kendala Guru Dalam Memberikan Penilaian Terhadap Sikap Siswa Dalam Proses Pembelajaran Berdasarkan Kurikulum 2013 Di SD Negeri 14 Banda Aceh.” Ilmiah Pendidikan Guru Sekolah Dasar. 